\title{
İnsan Sağlığı Esası Ekmeklik Buğday Kalite Yaklaşımları
}

\author{
Hasan KILIÇ ${ }^{1} \&$, Abdulkerim HATİPOĞLU ${ }^{2}$, Mehmet ŞAHİN ${ }^{3}$ \\ ${ }^{1}$ Tarla Bitkileri Bölümü, Ziraat Fakültesi, Bingöl Üniversitesi, Bingöl, TÜRKİYE. \\ ${ }^{2}$ Beslenme ve Diyetetik Bölümü, Sağlık Bilimleri Fakültesi, Mardin Artuklu Üniversitesi Mardin, TÜRKIYYE \\ ${ }^{3}$ Kalite ve Teknoloji Bölümü Bahri Dağdaş Uluslararası Tarımsal Araştırma Enstitüsü Müdürlüğ̈̈, Konya, TÜRKIYYE. \\ $\triangle$ : hkilic@ @ingol.edu.tr, iD 10000-0002-5242-9680, (D) ${ }^{2} 000-0002-1487-1953$, iD $330000-0003-2446-5227$
}

Geliş (Received): 16.02.2021Ｄüzeltme (Revision): 07.03.2021～Kabul (Accepted): 18.03.2021

\section{ÖZ}

İnsanlık tarihi kadar bir geçmişi olan buğday bitkisi, dünyada talebi artan stratejik öneme sahip sayılı gıdaların başında gelmektedir. Nişasta ve enerji kaynağı olmanın yanı sıra sağlık için gerekli protein, vitaminler, diyet lifi, fitokimyasallar ve antioksidan aktivitesi ile faydalı bir dizi bileşen muhtevasına sahip tam buğday danesi, insan metabolizması ve ihtiyacına göre yaratılmış en uygun gıda kaynağıdır. Yeşil devrim sonrası geliştirilen hexaploid buğday (Triticum aestivum L.) rafine edilmiş ürünlerinin diyabet, sindirim sistemi ve obezite gibi hastalıkların sebebi olarak gösterilmesi, kamuoyunda endişelere sebep olmuş bunun sonucu glutensiz ürünlere olan rağbet de artmıştır. Son yıllarda gelişitirilen çeşitlerde gluten oranı ve güçlülüğü bakımından genetik ilerleme oranlarında artış kaydedilmekle birlikte gluten ile indüklenen semptomların biyolojik esası yeterince izah edilememiş olup, glutenin çölyak dışı gluten hassasiyeti semptomlarını tetiklediği iddiaları da açık ve net değildir. Öte yandan tam buğday tüketiminin kardiyovasküler hastalık riski, tip-II diyabet ve bazı kanser türlerine yakalanma gibi kronik hastalıklarin gelişme riskindeki azalmayla ilişkilendirilmesi, toplumda ciddi talep oluşmasına paralel araştırıcıları da sağlık esaslı kalite özelliklerini belirlemeye itmiştir. Günümüzde kaba hacimli ekmek elde etmeye yönelik rafine unlarına ait belirlenmiş kalite özellikleri ile buna uygun geliştirilen çeşit zenginliği üretimin ihtiyacını karşılayabilmektedir. Ancak depo proteinlerinin belirleyici rol aldığı rafineri unlar için belirlenen kalite özelliklerinin kabuk/kepek (\%13-17) ve embriyo (\%2-3) kısmının dâhil edildiği tam buğday unlarının kalitelerinin belirlenmesine yönelik çalışmalarda ihtiyaca cevap vermede yetersiz kalacağı anlaşılmaktadır. Bu sebeple tam buğday ve mamüllerine ait kalite özelliklerinin belirlenmesi ile uygun işleme teknolojilerinin geliştirilmesi, uygun çeşit belirlemeye esas çalışmalarda ıslahçılara kolaylık sağlayacaktır. Yüksek tane verimine ek olarak insan sağlığına esas faydalı unsurların içerik ve kompozisyonları bakımından geniş bir varyasyona sahip ekmeklik buğdaylarda amaca uygun genotiplerin geliştirilmesi mümkündür.

Anahtar Kelimeler: Ekmeklik buğday, gluten, kalite ıslahı, sağlık, tam buğday

\section{Bread Wheat Quality Approaches Based on Human Health}

\section{ABSTRACT}

Wheat plant, which has a history as much as human history, is one of the few foods with increasing strategic importance in the world. In addition to being a major source of starch and energy, whole wheat grain, which contains a number of beneficial ingredients with protein, vitamins (notably B vitamins), dietary fiber, phytochemicals and antioxidant activity, is the most suitable food source created according to human metabolism and needs. The portrayal of hexaploid wheat (Triticum aestivum L.) refined products developed after the green revolution as the cause of diseases such as diabetes, digestive system and obesity has caused public concern and as a result, the demand for gluten-free products has increased. Although there has been an increase in genetic progression rates in terms of gluten content and strength in varieties developed in recent years, the biological basis of gluten-induced symptoms has not been adequately explained, and the claims that gluten triggers non-celiac gluten sensitivity symptoms are not clear. On the other hand, the association of whole wheat consumption with the reduction in the risk of developing chronic diseases such as cardiovascular disease risk, type-II diabetes and some types of cancer has led researchers to determine health-based quality characteristics in parallel with the serious demand in the society. Nowadays, variety richness developed in accordance with the specified quality characteristics of refined flours for obtaining coarse volume bread can meet the production needs. However, it is understood that the quality characteristics determined for refinery flours in which storage proteins play a decisive role will be insufficient to respond to the need in studies aimed at determining the quality of whole wheat flours, including shell/bran (13-17\%) and embryo (2-3\%). Therefore, determining the quality characteristics of whole wheat and its products and developing appropriate processing technologies will facilitate the breeders to determine the appropriate variety. In addition to high grain yield, it is possible to develop purpose-based 
genotypes in bread wheat, which has a wide variation in terms of nutrients and bioactive components required for healthy nutrition of people.

Key words: Bread wheat, gluten, health, quality breeding, whole wheat

\section{GíRIŞ}

Kültüre alınması günümüzden yaklaşık 12 bin sene öncesine dayanması yanı sıra yetiştiriciliği, hasadı, depolanmasındaki kolaylıklar ile insan fitratına uygun bir gıda olması gibi özelliklere sahip buğday, tüm dünyada stratejik bir ürün olarak önem kazanmıştır. İnsanlar için ihtiyaç duyulan günlük kalorinin $\% 19$ ve proteinin de $\% 21$ 'inin temin edildiği buğdayın $[1,2]$, dünyada üretimi 763 mil. ton olup bunun yaklaşık \%95'ini ekmeklik (Triticum aestivum L) geri kalan \%5'ini ise durum buğdaylar (Triticum durum Desf.) oluşturmaktadır [3]. Asya ve Afrika'nın bazı bölgelerindeki nüfus artışına paralel olarak gıda tüketimindeki talep artışının devam etmesiyle toplam tüketim son on yılın en yüksek seviyesine ulaşarak [3], global buğday tüketimi 66.8 $\mathrm{kg} /$ kişi'ye çıkmıştır [4]. Söz konusu global tüketimin 2027 yılına kadar çoğunlukla insan ihtiyacı olmak üzere $\% 13$ oranında artacağı beklenmektedir [5]. Hexaploid ekmeklik buğdaylarda yer alan üç genomdan DD genomundaki genler, hamur reolojisi ve dolayısıyla buğday ununun ekmek yapma özellikleri üzerinde derin bir etkisi olan proteinleri kodlamaktadır [6]. Öte yandan AA ve BB genomlarına sahip tetraploid Triticum durum Desf. buğdaylar ise protein özellikleri sebebiyle irmik üretimi için daha uygun olup daha ziyade makarna yapımında kullanılmaktadır [7]. Ekmeklik buğdaylar daneye uygulanan kuvvete göre sert ve yumuşak olmak üzere 2 kategoride değerlendirilmektedir [8]. Esas olarak ekmek yapımında kullanılan sert ekmeklik buğdaylar \%10-14 proteine oranına sahip iken, yumuşak ekmeklik buğdaylar (\%8-11) daha düşük protein oranlarına sahip olup pasta, kurabiye, kraker, simit gibi çok sayıda mamulde kullanılmaktadırlar [9]. Bu sebeple başta Türkiye olmak üzere $A B D$ ve Kanada gibi devletlerde yüksek proteinli ürünlere daha yüksek fiyat biçilmektedir. Yüksek protein ve güçlü glutenin esas kabul edildiği günümüz kalite anlayışında söz konusu unsurları artırmak adına lokal popülasyonlar, yabani akrabalar ve sentetik kaynaklardan istifade etme cihetine gidilmektedir. İnsan diyetinde en önemli g1da kaynağ [10] ve insan metabolizması için en uygun gıda maddesi olarak [11, 12] kabul edilen buğday, insanın g1da ihtiyacını karşılayabilen yegâne bir tür olarak yaratılmıştır. Gerek Tevrat ve gerekse Kur'an-1 Kerim gibi semavi kitaplarda buğdayın 1slahı, tüketimi ve muhafazası ile alakalı yöntem ve uygulamalardan bahsedilmesi [13, 14] söz konusu ürünün insan gıdas1 olarak mahzur teşkil etmeden kullanılabileceğinin bir delili olarak anlaşılmalıdır. Sayılan tüm faydaları ile birlikte, son zamanlarda buğdaydan mamul ürünlerin tüketiminin çölyak [15] ve diyabet [16] gibi bazı hastalıklar ile obeziteye sebep [17] olduğu ile ilgili beyanlar toplumda ciddi endişelerin oluşmasına ve tüketicilerin farklı beslenme kaynaklarına yönelmesine sebep olmuştur. Nitekim son zamanlarda glutensiz diyetlere olan talepteki artış dikkati çekmektedir. Hâlbuki Çölyak hastalığı genetik yatkınlık ile ilgili bir durum olup [18] genellikle buğday, çavdar ve arpa gibi tahillarda bulunan gluten tarafindan tetiklenen otoimmun bir bağırsak hastalığıdır [19].

Temel gıda konumundaki buğdayın işlenmesindeki teknolojiler, özellikle de mikrolement ve antioksidantların büyük oranda dane kabuğuyla birlikte atıldığı güçlü glutene sahip beyaz undan yapılan ürünler ile ilişkilendirilen çölyak, buğday alerjisi ve çölyak diş1 hastalıkların cemiyette görülme oranı sirasıyla $\% 1, \%$ $0,63-6$ ve $\% 0,1-0,6$ 'dir $[20,21]$.

Gluten hangi durumlarda zararlı olabilmektedir? Buğday temelde rafine veya rafine edilmemiş şekilde tüketilmekte olup farklı formlardaki tüketim, insan sağlı̆̆ında farklı etkilere sebebiyet verebilmektedir [22, $23,16]$. Bu sebeple glutenin farklı işlenmiş buğday ürünlerindeki etkisi ayrı ayrı değerlendirilmelidir. Son yıllarda çölyak dişı buğday hassasiyetinde artan yaygınlığın sebebi tam bilinmemekle birlikte, modern buğday işleme teknikleri, tüketicinin immünoreaktif bileşiklere maruziyetini artırma ihtimali üzerinde de durulmalıdir [24]. $\mathrm{Bu}$ itibarla insanlarda artan hassasiyetin kaynağını bulmada buğday mamulleri ile birlikte una katılan katkı maddeleri ve uygulanan teknolojiler eşzamanlı olarak gözlem altına alınmalıdır. Ayrıca çok sayıda sebebi olmakla birlikte glutensiz diyetlere olan talepteki bu artış hızında en önemli unsurun güçlü gluteni ihtiva etmeyen diyetlerin sağlık bakımından faydalı olduğu hususunda oluşan kamuoyu inanc1 olduğu tahmin edilmektedir [25, 26]. Zira Biesiekierski ve ark. [27] çölyak hassasiyeti olanlar dışında da glutenin zararlı olduğu ile ilgili raporların biyolojik temelinin belirsiz olduğunu bildirmişlerdir. $\mathrm{Bu}$ sebeple bir kısım beslenme uzmanının sağlıklı insanlar için gluteni veya güçlü gluteni tümüyle zararlı göstermelerine temkinli yaklaşmak gerekir. Güçlü glutenin insan sağlığına zararlı olduğu ile alakalı kapsamlı ve çok faktörlü araştırmalara ihtiyaç vardır. Niland ve Brooks [28], çölyak gibi gastrointenstinal irsi hastalıklarda glutensiz diyetlerin faydalı olmakla birlikte bu tür alerjik durumu olmayan insanlarda glutenden kaçınmayı destekleyen ikna edici bir sonucun mevcut olmadığını, Wünsche ve ark. [29] glutenin insan metabolizması için gerekli olduğunu ve tüketmeyenlerde ağır metal birikimi dahil ek sağlık sorunlarını ortaya çıktığını; Zong ve ark. [30], sağlıklı insanlarda gluten alımı ile Diyabet-2 arasında ters bir ilişki bulunduğunu, genel popülasyondaki gluten alımının tip 2 diyabet riskinin artmasına katkıda bulunmasının muhtemel olmadığını, diyetteki gluteni sınırlamak, tahıl lifinin daha 
düşük alımı ve muhtemelen sağlığa katkıda bulunan diğer faydalı besinlerle ilişkili olduğunu bildirmişlerdir Buğday glutenin insan sağlığı üzerinde etkileri ile alakalı çalışma yapan araştırıcılar sorunun tam buğdayın tüketilmemesinden kaynaklı olabileceği ihtimaline odaklanmaları daha isabetli olacaktır. Rafineri beyaz unun elde edilmesinde buğday tanesinde insanlara faydalı proteinler ve önemli minerallerin elemine edilmesi sonucu üretilen ekmeklerin yeterince besleyici olmaması bahsedilen mahzurların ortaya çıkmasında en önemli muhtemel faktörlerdir. $\mathrm{Bu}$ amaca uygun olarak buğday tanesini bir bütün olarak değerlendiren çok sayıda araştırma yapılmıştır.

Mevcut çalışmalar tam tahıl tüketiminin insan sağlığına katkı sağladığını, günde 2-3 porsiyon tüketenlerin 2 porsiyon tüketenlere göre önemli oranda daha düşük felç, kalp rahatsızlığ 1 , diyabet-2 ve sebebi bilinmeyen ölümlere maruz kaldıklarını göstermektedir [31, 32]. Vitaminler, mineraller, lignin ve fotokimyasallarca (fenolik asitler, ployphenol ve phtosterol bileşikleri) zengin endosperm, embriyo ve kabuktan müteşekkil, tam buğday ile beslenmenin beyin sağlığı ile birlikte kanser, kalp hastalıkları, diyabet, hipertansiyon ve obezite riskine etkisi ile ilgili yapılan çalışmalarda olumlu sonuçlar elde edildiği bildirilmektedir [33, 34, 5]. Burada önemli olan, farklı buğday türlerinden ziyade fitrata uygun sağlıklı ürün işlenmesi ve dengeli beslenme ile alakalı tedbirlerin alınmasıdır. Varlık âleminde yaratılan tüm canlılar arasında bir düzen söz konusudur. Bitki, hayvan ve insanlar arasında var alan besin zinciri, bir denge ve dönüşüm kanununa bağladır. Her bitki türünün makamında üstünlüğü vardır. Ancak aynı türün farklı genotipleri arasinda adaptasyon, verim, canlı cansiz faktörlere mukavemet bakımından farklılıklar olması beklenen bir durumdur. Yakın geçmişte yapılan çalışmalarda gerek kavuzlu ve gerekse hexaploid buğdaylar arasında çölyak immunojinitesi bakımından geniş bir varyasyonun varlığı [35-38] amaca uygun genotipleri geliştirmede islahçılar için bir kolaylık olarak kabul edilmektedir.

İnsan sağlığı ve tüketimi ile alakalı ıslah çalışmalarında danenin bir bütün olarak değerlendirilmesine önem verilmelidir. Diğer tüm özelliklerin ihmal edilip tek bir özellik yönünden seleksiyon yapılması birbiriyle dengeli bir münasebet içerisinde bulunan özelliklerde artma veya azalmaya sebebiyet verecektir. $\mathrm{Bu}$ genel kanaat ile birlikte sağlık açısından tanenin tüm veya bileşenlerinin ayrı ayrı etkilerinin açığa kavuşturulması, endişeleri gidermesi yanında ıslahçı ve sanayicinin gerekli tedbirleri alması açısından önem arz etmektedir. Öte yandan ilaç endüstrisi, çölyak hassasiyeti, yem rasyonlarına esas kepek oranının yüksek olması vb diğer özel amaçlar için tanedeki bir özellik yönünden spesifik amaçlı genotiplerin geliştirilerek üretime kazandirılmasının bir mahzuru bulunmamalıdır. Bir kısım gastroenterolog ve diyetisyenlerin hexaploid buğday ile alakalı çelişkili beyanları çölyak olmayan ve kısmen gluten allerjisi olan ve olmayan tüketicilerde meydana getirdiği olası endişeler açıklığa kavuşturulmak üzere tam tahıl ve aşırı işlenmiş rafine buğday ürünlerinin olası etkileri ayırt edilmelidir. Bu derlemede çalışmasında insan sağlığını esas alan tam buğday kalite bileşenleri ve özellikleri ile uygun genotipler üzerinde durulmaya çalışılmıştır.

\section{Yeşil Devrim İle Başlayan Islah Stratejisi}

Yeşil devrim öncesine kadar yerel populasyon ve çeşitler mevcut nüfus ve günün ihtiyaçlarına cevap verebilmekteydi. Yaygın buğday olarak kabul edilen hexaploid ekmeklik buğdaylarda gerek kalite ve gerekse tane verimi bakımından yabancı döllemenin sınırlı olmasına bağlı eski yerel populasyonlarda orijinal çeşitliliğin yetersiz olması ile birlikte Tadesse ve ark. [2], daha çok bölgesel olarak hedeflenen 1slah amaçları yaygın olmayan hastalıklar, gelişmemiş teknoloji ve diğer birçok faktöre uygun olarak melezlemeler yapılmakta ve kısmen verim artışı sağlanmakta idi. Bilahare artan nüfus, makineleşmenin hızlanması ve buna bağlı tarla alanların genişlemesi ve sulama imkânlarının artması ıslahçıları farklı arayışlara itmiştir. CIMMYT araştırıcılarından proje lideri Norman Borlaug buğdayın daha geniş alanlara ekilmesinde en önemli unsurun fotoperyoda duyarsız çeşitlerin ıslahı etmekle mümkün olduğunu bildirmiştir. $\mathrm{Bu}$ amaçla araştırıcı grubu tarafından 1968 yılında başlangıçta çok fazla eleştiriye rağmen nihayette büyük beğeni toplayan mekik 1slahı (Shuttle breeding) yöntemiyle farklı enlem ve boylamlardaki agroklimatik şartlar ve lokasyonlarda $\mathrm{Ppd}_{1}$ ve $\mathrm{Ppd}_{2}$ genlerini içeren fotoperyoda hassas olmayan hatlar geliştirilmiştir [39]. Hexaploid buğdaylar genetik olarak uzun gün bitkileri olmakla birlikte farklı lokasyon ve iklimler fotoperyoda duyarsız kısa günlerde başaklanmayı gerektiren genotiplere de ihtiyaç duyulmaktadır. Temeli tam anşalılmamakla birlikte fotoperyoda duyarsızlığın $\mathrm{A}, \mathrm{B}$ veya $\mathrm{D}$ genomlarındaki Ppd-1 genindeki mutasyonlardan kaynaklandığ 1 tahmin edilmektedir [40]. Orijini kesin olmamaklla birlikte Türkiye'den geldiği tahmin edilen ilk bilinen kırmızı sert yazlık buğdayların 1842 yılında "David Fife" ismiyle ABD'de yetiştirildiği [41], Çin yazlık buğdayı olarak bilinen beyaz lokal bir çeşidin de Çin'in Siçuan bölgesinde eskiden beri yetiştirildiği bildirilmektedir [42]. Bilahare kısa boylu ( $\mathrm{Rht}_{1}$ ve $\mathrm{Rht}_{2}$ genleri) pasa dayanıklı hatların [43] geliştirilmesi ile pleiotropik etkiler sonucu yüksek biyokütleye eşlik eden yüksek tane verimine sahip hatların [44] yağışı yüksek yerlerde de yetiştirilmesi mümkün olmuştur. Türkiye buğdayın gen kaynağı olmakla birlikte şu ana kadar gerek sahil ve gerekse orta Anadolu'da keşfedilen yerel ekmeklik buğdaylar içinde fotoperyoda duyarsız lokal tiplere rastlanılmamıştır. Yeşil devrim sonrası bilhassa sahil ve Güneydoğu Anadolu'da CIMMYT'in fotoperyoda duyarsız Penjoma-62 gibi çeşitlerin ekimi hızla artmış ve verimde bir patlama yaşanmıştır.

Artan ihtiyaçlar, canlı ve cansız stres faktörlerinin yeni bir boyut kazanması ile birlikte moleküler biyoloji 
alanındaki gelişmeler ıslahçıları farklı arayışlara bilhassa yabanilerinden istifade etme cihetine itmiştir. Bu itibarla 1980'li yılların sonlarında genetik varyasyonu genişletmek üzere sentetik hexaploid ekmeklik buğdaylar geliştirilmiştir. Esasını AA ve BB genomunu taşıyan tetraploid durum buğday ve DD genomunu taşıyan diploid yabani buğdayların çaprazlanması ( $T r$. durum $\mathrm{x}$ Ae. tauschii) ile elde edilen melezlerin kromozom katlanması sonucu $(6 \mathrm{x}=42)$ AABBDD genomuna sahip sentetik hexaploid poliploid buğday hatları elde edilmiştir. Günümüzde CIMMYT’nin geliştirdiği modern buğday hatları içindeki sentetik hexaploid buğday hatlarının payı \%20 civarındadır. Yüksek tane verimi ve adaptasyon kabiliyeti ile birlikte canl1-cansız faktörlere dayanıklı ve daha iri tane ve başak özellikleri ile öne çıkan sentetik hexaploid buğdaylar günümüzde dünyanın farklı ülkelerinde ıslah programlarında geniş bir oranda kullanılmaktadır [45, 46]. Ancak Aktaş ve ark. [47], kışlık tabiat özelliğindeki sentetik ile modern ekmeklik gruplar arasında dane iriliği dışında gerek verim ve gerekse incelenen kalite özellikleri yönünden bir farkın tespit edilemediğini bildirirlerken, diğer bazı araştırıcılar da insan beslenmesi için önemli sayılan $\mathrm{Fe}$ ve $\mathrm{Zn}$ bakımından sentetik hexaploid ekmeklik buğdayların daha zengin olduğunu bildirmektedirler [48]. Yukarıda bahsi geçen yöntemleri kâfi görmeyen tahıl 1slahçıları, mısır gibi yabancı döllenen bitkilerde uygulanan sitoplazmik erkek kısırlık (cytoplazmic male sterility) teknolojisini 1990'lı yıllardan sonra tahıllar üzerinde yoğunlaştırmışlardır. Saf hatlara göre sağlanan \%10-20'lık verim avantajı yanında, kalite, gübreye reaksiyon ve kök penetrasyonu bakımından daha etkin olan hibrid buğdaylar, günümüzde bazı Avrupa devletleri başta olmak üzere, Hindistan, Çin ve ve ABD'de çok sayıda çeşit geliştirilerek ticari olarak geniş alanlarda yetişme imkânı bulmuştur [49-51]. Buğdayın sahip olduğu çeşit ve yakın akraba türlerin zenginliği gerek verim ve gerekse kalitede geniş bir varyasyonun oluşmasına ve 1slahçıların arzu edilen özelliklere ulaşmada zorluk yaşamamaları GDO teknolojisinin bu üründe kullanımını sınırlandırmıştır. Buna rağmen bazı araştırıcılar başta tane verimi olmak üzere stres şartlarına mukavemet ve kalite özelliklerinde tahıl grubuna dâhil mısır, arpa ve çeltik gibi türlerden gen transferini gerçekleştirmişlerdir. Bu amaçla, artan sıcaklık stabilitesi ile birlikte çözünür nişasta sentezini kodlayan genin varlığını (OsSS-1) tespit eden Amerika'lı bir araştırıcı grubu yüksek sıcaklık şartlarında transgenik buğdayın $\mathrm{T}_{2}$ ve $\mathrm{T}_{3}$ generasyonlarında kontrole göre \%21-34 oranında verim artışı sağladıklarını bildirmişlerdir [52]. Benzer çalışmalar buğday kalite parametrelerinde de sürmüştür. Protein oranını artırmaya yönelik çalışmalarda Weichert ve ark. [53] arpa sakaroz genini (HvSUT1) transfer etmek suretiyle transgenik buğday tanelerinde nişasta seviyesinde bir değişiklik olmadan sakaroz alımı ve protein içeriğini artırdıklarını rapor etmişlerdir. Transgenik buğday çalışmaları sadece bunlarla sınırlı olmayıp, örneğin hamur özelliklerini belirleyen yüksek molekül ağırlıklı glutenin alt birimlerinin (HMW-GS) kodlayan genlerin farklı buğday genotiplerinden transferi suretiyle yeni genotipler geliştirilmiştir [54, 55]. İlim dünyasında transgenik buğday geliştirme çalışmaları sürmekle birlikte insan sağlı̆̆ ve çevreye olan muhtemel olumsuz etkilerdeki belirsizlik ve endişeler ile birlikte kamuoyunun tepkisi vb. sebeplerden dolayı günümüzde Arjantin dışında ticari transgenik buğday üretiminin yapıldığı ülke bilinmemektedir.

Dönemin ihtiyaçlarına göre ıslah amaçlarını belirleyen 1slahçılar mikrolement içeriği kısmen ihmal etmekle birlikte hastalık ve zararlılar ile cansız faktörlere toleranslık, adaptasyon, protein kalitesi gibi unsurlar yönünden gerek dünyada ve gerekse ülkemizde çok sayıda buğday çeşidi geliştirerek üretime kazandırmışlardır. Bütün bunlarla beraber tane veriminde potansiyel hedefe ulaşıldığı söylenemez [13]. Sibirya'da 1900-2010 yılları arası yazlık ekmeklik buğdayların mukayese edildiği çalışmada verimde genetik kazancın yıllık \% 0.59 olduğu, 1976-1985 yılları arasında alveograf $\mathrm{W}$ enerji değeri, fariniograph yoğurma zamanı ve yumuşama derecesi gibi hamurun fiziki özellikleri yönünden önemli oranda üstünlük kaydedildiği, 19501975 yılları arası ise ekmek hacmi bakımındanda önemli gelişme (\%15.6) sağlanırken $\mathrm{Zn}$ ve Fe bakımından ise bir değişikliğin olmadığ belirtilmektedir [56]. Bornhofen ve ark. [57], Brezilya'da 1920-2010 arası geliştirilen veya ileri hat 458 yazlık ekmeklik buğday genotipi ile ekmeklik kalitesinde meydana gelen genetik ilerlemenin oranını belirlemek üzere yürüttükleri çalışmada Gluten kuvveti için (W) y1llık \%1.3 olarak tespit ettiklerini bildirmişlerdir.

Ülkemiz şartlarında yazlık buğdaylarda 1964-2010 yılları arası geliştirilen çeşitlerde verim bakımından genetik ilerleme y1llı $30.9 \mathrm{~kg}$ olarak belirlenirken, kalite özelliklerindeki gelişme ise protein oranından ziyade protein kalitesini belirleyen fraksiyonlarında kaydedildiği rapor edilmektedir [58]. Tüm bu çalışmalar sonucu yaygın ekmeklik buğdaylarda yüksek tane verimine sahip buğday çeşitlerinin hızla yayılması lokal çeşitlerin üretimlerinin azalması ile birlikte genetik erozyonu hızlandırmıştır [59]. Artan dünya nüfusunun ihtiyacını karşılama adına yapılan söz konusu çeşit geliştirme çalışmaları ve verimde sağlanan artışlar 1990'l1 yıllara kadar Dünya nüfusuna yetecek seviyeye gelmiştir. Artan refah seviyesi, tahıl teknolojisindeki gelişmeler, mamül tahıl ürünlerindeki çeşitlilik 1slahçıları farklı kalite seviyelerindeki çeşit arayışına sevk etmiştir. Islahçılar çoğunlukla Amerikan gida kültürüne uygun kaba hacimli somun ekmek elde etmeye esas kalite kriterleri üzerinde yoğunlaşmıştır. Geçmişte protein miktarı üzerinde durulurken günümüzde protein oranı ile birlikte kalitesi daha da ön plana çıkmaktadır. Yüksek hacimli ekmek elde etmenin en önemli kriteri kabul edilen gluten kuvveti (güçlülüğü) ve bunu ölçmede yaygın olarak kullanılan Zeleny ve SDS sedimentasyon testleri önemli bir kalite özelliği olarak ön plana çıkmıştır. Yüksek verimine rağmen düşük SDS ve düşük 
alveoragraf değerlerine sahip genotipler elemine edilmiştir. Öyleki baharlık buğdaylarda 1950-1975 yılları arası geliştirilen çeşitlerde ekmek hacmi bakımından $\% 15$ bir üstünlük temin edilmiştir [56].

Bilahare kalite özelliklerini ölçen Farinograf, Alveograf, Miksograf gibi aletlerin kullanılması ile buğday kalite özelliklerini ölçmedeki yelpaze daha da genişlemiştir. Günümüzde değirmenci, firıncı ve tüketici isteklerine uygun çeşitler daha kolay ve hızlı belirlenebilmektedir. Çeşit geliştirme çalışmalarında danedeki mikrobesin içeriğinin pek önemsenmediği geçmişte, 2010'lu yıllarda bazı ülkelerde $\mathrm{Fe}$, Se, ve $\mathrm{Zn}$ gibi mineral eksikliğinden kaynaklanan hastalıkların artması ve çocuk mamaları ile gıdalara söz konusu minerallerin takviye edilmeye başlanması sebebiyle seleksiyonda söz konusu minerallerce zengin genotipler de seçilmeye başlanmış, güdümlü melezlemeler ile birlikte yakın akraba türlerinden istifade edilme cihetine gidilmiştir. Mikro besin öğeleri yönünden zengin genotiplerin geliştirilmesi yönündeki çalışmalar, rafineri beyaz ekmeğin kullanımı ile önemini kaybetmektedir. Çünkü mikroelementlerce zengin ve kepek olarak değerlendirilen mikroelementlerce zengin (\%4.6-5.3) kabuk k1smı ile embriyo (\%3) rafineri beyaz undan uzaklaştırılmaktadır. Beyaz unu oluşturan endospermde mineral madde oranı yalnızca $\% \quad 0.3$ iken tüm tane de de \%1.3-2.5 civarındadır. Rafineri un elde edilirken maalesef endosperm dışındaki tüm unsurlar büyük oranda elek üstü olarak ayrılmakta ve kepek olarak değerlendirilmektedir.

\section{Buğday Danesi ve Muhteviyatı}

Buğdayın temel olarak durum ve ekmeklik olmak üzere 2 farklı tipi vardır. Durum buğdaylar daha ziyade makarna, bulgur, kuskus, köfte vb amaçlar için kullanılırken, ekmeklik buğdaylar çoğunlukla ekmek yapımında kullanılmaktadır.

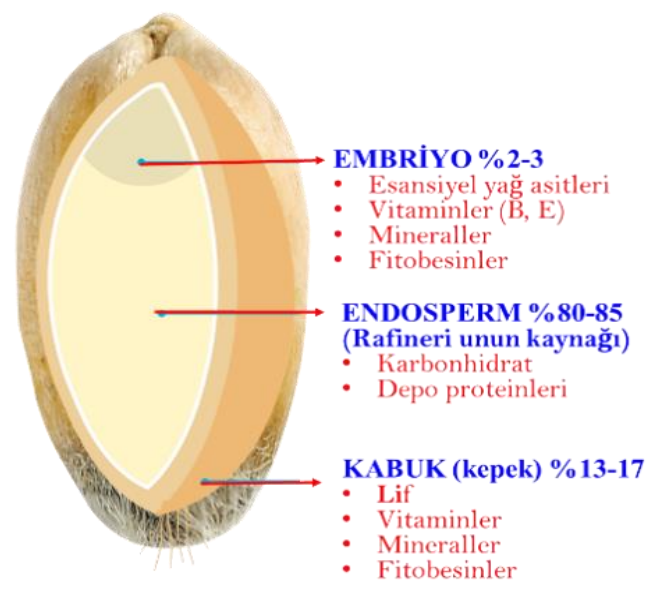

Şekil 1. Buğday danesi temel unsurları

Ekmeklik buğdaylar da sert ve yumuşak olmak üzere iki sınıfa ayrılmaktadır. Daha yüksek protein ve gluten oranına sahip sert buğdaylar ekmekçilikte kullanılırken, daha düşük protein oranına sahip yumuşak buğdaylar ise kek, bisküvi vb. sahalarda değerlendirilmektedir. Ayrıca farklı oranlarda protein içeren spelta (kavuzlu), emmer (Gernik-Kavılca), einkorn (siyez) ve kamut (Horasan buğdayı) gibi buğdaylar da benzer amaçlar için kullanılmaktadır. Bir buğday danesi ekseriyetle karbonhidratlar, proteinler, lipitler ve minerallerden oluşur (Şekil 1 ve Şekil 2).

İnsanların temel besin öğeleri durumundaki bu unsurlar, çok az insanda olumsuz tesirlere sebebiyet verebilmektedir. Ancak bazı proteinler ve fruktanlar bazı hassas insanlarda (çölyak) sindirimde parçalanması zor olan yapılara sahiptir [24].

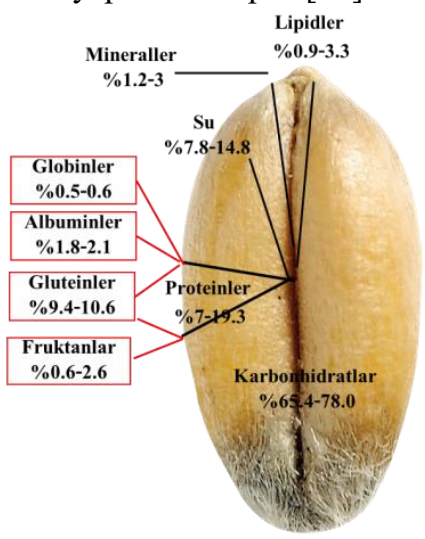

Şekil 2. Buğday danesindeki temel unsurların dağılımı [60-65, 24].

\section{Buğday Depo Proteinleri ve İnsan Sağlığı}

Buğday proteinleri, gluten, globulin ve albümin adı verilen 3 ana unsura ayrilabilir. Bunlardan gluten (proteinin \%60-80), suda çözünmeyen gliadin ve glutenin ismi verilen iki alt unsurdan oluşan karmaşık bir özelliğe sahiptir. Bilindiği üzere glutenin ve gliadinler buğdayın bilinen en önemli depo proteinleri olup toplam proteinin yaklaşı $\%$ 60-85'ini teşkil etmektedirler. Gluten ise gliadin ve gluteninin uygun koşullarda (su, asitlik, yoğurma vd.) biraraya gelmesiyle elde edilen bir protein kompleksidir. Gliadin, hamurun viskositesini kontrol ederken, glutenin de hamurun gücü veya elastikiyetine ait özellikleri kontrol etmektedir [66-68]. SDS-poliakrilamid jel elektroforezindeki (SDS-PAGE) moleküler ağırlıklarına göre ayrılan ve hamurun elastikiyetinden sorumlu gluteninler ise yüksek molekül ağırlıklı (HMW-GS) ve düşük molekül ağırlıklı LMWGS olmak üzere iki alt gruba ayrılmaktadır [69-72]. Kamuoyunda diploit, tetraploid buğday ve çavdar gibi tahıllardan elde edilen mamüllerin çölyak hastaları için daha az zararlı olduğu ile ilgili beyanlar ve söz konusu ürünlere olan talebin artması araştırıcıları bu konulara sevk etmiştir. Siyez (AA genomu) kavılca ve durum (AABB genomu) gibi buğdayların çölyak hastaları için hexaploid buğdaylardan daha sağlıklı olduğuna dair yapılan çalışmalar mevzuyu kısmen destekler nitelikte olup, genom bileşimi çölyak immün reaksiyonundaki değişimi kısmen açıklayabilmektedir. Çok yüksek immünojenik $\alpha$-gliadinler, buğdayın $\mathrm{D}$ genomu tarafindan kodlanmakta [73-75] olup, AA ve BB 
genomlarına sahip tetraploid emmer ve durum buğdayları genellikle AABBDD genomuna sahip hexaploid ekmeklik buğdaylardan daha az, ancak AA genomuna sahip diploid siyezden (einkorn) daha fazla immün reaksiyonlu görünmektedir [24]. Buna benzer sonuçları destekleyen araştırıcılar olmakla birlikte [76], günümüzde birçok araştırıcı da gerek diploit ve gerekse tetraploid buğdayların immun reaksiyonu bakımından diğer buğdaylardan farkının olmadığını bildirmişlerdir. Bunlardan Shewry ve Hey [77]; Shewry ve Hey [78] çalışmalarında einkorn, emmer, spelta ve Horasan (Kamut) buğdaylarının sağlık açısından günümüz ıslah edilmiş hexaploid yaygın ekmeklik buğdaylardan daha üstün olduğunu destekler bulgular elde edemediklerini, Zanini ve ark. [79], AA genomuna sahip Triticum monococcum gibi diploid buğday türlerinin çölyak hastaları tarafindan tüketilmesinin güvenli olmadığını, Malalgoda [38] bulgularında siyez-einkorn (Triticum monococcum), gernik-emmer (Triticum dicoccum) ve kamut (Triticum turgidum subsp. turanicum) gibi buğday ile çavdarın (Seceale cereale L) çölyak hastalığı ile ilişkilendirilen immunojiniteyi ortaya çıarma potansiyeline sahip iken teff (Eragrostis tef) ve sorgum (Sorghum bicolor Moench ssp. Bicolor) gibi tahilların protein ekstraktlarında ise söz konusu epitoplar bulunmadığını bildirmişıledir.

Günümüzde üzerinde en çok durulan ve kamuoyunu meşgul eden unsur gluten olmaktadır. Buğdaydan mamul ürünlerin çölyak hastalarında oluşturduğu olumsuz etkilerin hassasiyeti olmayan insanlarda da benzer etkiyi tetikleyeceği inancı cemiyette glutensiz ürünlere olan talebi artırmıştır. Bu bağlamda, diploid, tetraploid ve hexaploid türler ile yerel popülasyon ve 1970 sonrası 1slah edilen buğday genotiplerindeki glutenin insan metobolizması üzerine etkisi ile alakalı çok sayıda çalışma yapılmakla birlikte tüketicilerin şüphelerini izale etmeye kâfi gelmemiştir. Özellikle 1970 sonrası sentetik çeşitler dâhil olmak üzere geliştirilen hexaploid yaygın buğday çeşitlerinin hazımlarının güç olduğu, hastalıklara davetiye çıkardığı ile alakalı iddialar komuoyunda çokça paylaşılmaktadır. Ayrıca, gluteninin sızdıran bağırsak sendromunu artırarak diyabete sebebiyet verdiği ile alakalı araştırma sonuçları da vardır. Zonulin, ince bağırsağın sıkı bağlantılarını tanzim eden bir proteindir. Zonulin bağırsaklarda ifraz edildiğinde sıkı bağlantılar hafifçe açılır ve daha büyük parçacıkların bağırsak duvarından geçmesine imkân verir [80, 81]. Test çalışmalarında, glutenin çölyak ve çölyak olmayan bireylerde zonulini aktive etmesi sonucu bağırsak geçirgenliğinin artmasına sebep olduğu bildirilmektedir [82, 83]. Ancak başka çalışmalar çölyak olmayan bireyler açısından farklı sonuçların elde edildiğini rapor etmektedirler. Test tüpü çalışmaları, gluteninin bağırsak geçirgenliğini artırdığını göstermekle birlikte insan çalışmalarında bunu doğrular nitelikte araştırma sonucunun bulunmadığı bildirilmektedir [84]. Glutenin çölyak hastalarında zonulini aktive ettiği kesin olmakla birlikte [85] sağlıklı insanlarda sızdıran bağırsak sendromunu artırdığına dair deliller karmaşı ve yetersizdir [86]. Beslenme uzmanlarının çoğu kandaki şeker oranını hızlı bir şekilde artırdığı için beyaz undan yapılan ekmekleri tavsiye etmezler. Halbuki kandaki şeker oranının önemli bir ölçüsü olan glisemik indeks değeri buğdaya eşdeğer veya daha yüksek değerlere sahip besinler olmakla birlikte buğday yegane faktör olarak gösterilmektedir. Çok sayıda çalışma şeker oranını artırıcı unsur olarak buğdaydan ziyade, buğdayın ögütülmesi ve pişirme tekniği gibi farklı teknolojik değerlendirmelerin daha etkili olduğunu göstermektedir. Öğ̈̈tme oranı ve pişme süresi artıkça ürünün glisemik indeks değerleri de artmaktadır. Çalışmalar, daha iri ögütülmüş durum buğday irmiğinden yapılan sıradan makarnanın glisemik indeksi değerinin (47) ekmeklik buğday makarnasından (68) ve pişmiş pirinçten (73) önemli ölçüde daha düşük olduğunu göstermiştir [87, 88]. Modu [89], durum buğdaydan yapılmış spagettinin glisemik indeks değerinin gerek beyaz ekmek ve gerekse kabuğu soyulmuş ve soyulmamış buğdayın glisemik değerlerinden daha düşük olduğunu bildirmektedir. Ekmeklerin lif miktarları arttıkça glisemik indeks değerleri de azalmaktadır [90]. Bazı buğday ürünlerine ait glisemik indeks değerleri Tablo 1'de verilmiştir.

Tablo 1. Buğday ve bazı mamullerine ait glisemik indeks değerleri [91].

\begin{tabular}{llll}
\hline Besin & $\begin{array}{l}\text { Glisemik } \\
\text { indeks } \\
\text { (glikoz=100) }\end{array}$ & $\begin{array}{l}\text { Porsiyon } \\
\text { büyüklüğü } \\
\text { (gr.) }\end{array}$ & $\begin{array}{l}\text { Glisemic } \\
\text { yük/pors. }\end{array}$ \\
\hline Beyaz buğday ekmeği (ort.) & 75 & 30 & 11 \\
Tam buğday ekmeği (ort.) & 69 & 30 & 9 \\
Buğday saç ekmeği (lavaş) & 30 & 50 & 8 \\
Tam buğday danesi (ort.) & 45 & 50 & 15 \\
Bulgur, (ort. & 47 & 150 & 12 \\
Makarna (ort.) & 50 & 180 & 24 \\
\hline
\end{tabular}

*: Glisemik değerleri araştırma sonuçlarında farklılık gösterebilmektedir.

Toplumda görülme sıklığı \%6 civarında [92] olan "çölyak dışı gluten hassasiyeti”nin (ÇDGH) geçmişte glutenin sebep olduğu inancı günümüzde yapılan detaylı araştırmalarla değişmeye başlamıştır. Gluten ile indüklenen semptomların biyolojik esası bilinmemekle birlikte glutenin ÇDGH semptomlarını tetiklediği iddiaları da açık ve net değildir [93]. Öte yandan bir gastroentolog olan Muir [94], çölyak dişı gluten hassasiyetinin glutenden olmayı, "fruktan" adlı bir karbohidrattan kaynaklandığını rapor etmektedir. Bilindiği üzere Fruktan; tahıllardan en çok durum buğdaylarda olmak üzere yanı sıra pırasa, soğan, sarımsak bezelye, karpuz, beyaz şeftali ve muz gibi bazı bitkisel besinlerde de bulunmaktadır. Daha düşük glisemik değer ve hexaploid ekmeklik buğdaylardan daha düşük immün reaksiyon göstermeleri [24] durum buğdayların gerek ekmek ve gerekse diğer mamulleri için kullanılmalarının sağlık açısından araştırmaya değer bir konu olduğunu belirtmekte fayda vardir.

Buğday depo proteinleri için kodlama bölgeleri farklılık arz ettiğinden [95-97] her genotip benzersiz tip ve miktarlarda gluten, amilaz tripsin inhibitörleri ve fruktan 
üretir [98]. Ekmeğin teknolojik özelliklerini belirlemeye yarayan yüksek (HMW-GS; LMW-GS) ve düşük molekül ağırlıkları bakımından buğday genotipleri arasında büyük varyasyon olduğu belirlenmiştir [71, 72]. $\mathrm{Bu}$ açıdan ıslahçı açısından insan sağlığını esas alan genotiplerin belirlenmesinde GDO'ya gerek duymadan hedefe ulaşmak zor olmayacaktır. Bu itibarla söz konusu buğdaylarla alakalı çalışmaların genetik, 1slah, beslenme ve tibbi bilimlerin ilgili sahalarında uzman ekiplerin birlikte yapacakları değerlendirmelerle mevzu daha net izah edilerek endişeler giderilebilmelidir.

\section{Tam Buğday Kalite Parametreleri}

Tam tahıllı buğday ununda (TTBU), bozulmamış formda endosperm, kepek ve ruşeym gibi tahılın tüm anatomik bileşenleri mevcuttur. Bu sebeple, TTBU, rafine buğday ununa göre (RU) çok daha fazla lif, vitamin, mineral ve fitokimyasallar ihtiva etmektedr [99]. Tam buğday, tip 2 diyabet, kardiyovasküler hastalıklar, obezite ve kanser gibi kronik hastalıkların risklerini azaltmaya yardımcı oldukça değerli ve işlevsel bir besin kaynağı olarak kabul edilmektedir [100-104]. Tam tahıl içerikli gıdalar karbonhidrat, lif, protein, B grubu vitaminler E vitamini, $\mathrm{Fe}, \mathrm{Zn}, \mathrm{Cu}, \mathrm{Mg}$ ve çeşitli antioksidanlar içerir [105]. Kepekli tahılların koruyucu özelliklerini diyet lifi ve diğer bileşenlerden ayırmak zor olmakla birlikte, epidemiyolojik çalışmalarda kepekli tahılların hastalıklardan korumada kepekli tahıllardan izole edilmiş besinlerdeki ve fitokimyasallardaki korumadan çok daha etkilidir [106]. Gramineae ailesine mensup buğday, çok verimli tıbbi değerlere sahip ve kepeğinde çeşitli tedavi edici ilaçlar ihtiva etmesinden, kabızlık, kalp hastalıkları, apandisit, obezite, diyabet ve divertikül adı verilen kolon hastalıkları gibi çeşitli hastalıklara karşı koruma sağlamaktadır [107]. Alınan gıda türü ve işlenme şekline göre tip I ve II diyabetin önemli bir göstergesi olan kandaki glisemik indeks değeri değişebilmektedir. Bütün halinde uygun ögütülmüş bir buğday mamülü yavaşça glikoza dönüşmek suretiyle uzun süreli tok tutarken, rafineri undan elde edilen buğday ürünleri ise kandaki glikoz seviyesini hızlı bir şekilde yükseltmek süretiyle glisemik indeksinin artmasına sebep olmaktadır. Buna bağlı olarak karaciğer ve pankreas fonksiyonlarının bozulması sonucu başta diyabet olmak üzere obezite ve diğer ilişkili hastalıklar ortaya çıkmaktadır [108]. Tablo 1 'de rafinesyonla buğdayın besin içeriğinde meydana gelen kaybın (protein ve nişasta hariç tutulduğunda) \%48-92 civarında olduğu görülmektedir (Tablo 2). Meyve ve tohum kabuğu birbirine yapışık karyopsis durumundaki buğday tanesinin rafine edilmeden içerdiği besin öğelerinin insan metabolizması ile uyumlu olması bir bütün olarak tüketilmesi gerektiğinin en önemli delilidir. Halbuki yerfıstığı, mercimek ve nohut gibi tohumu meyve kabuğu ile bitişik olmayan türlerde tohumun meyve kabuğundan ayrılarak tüketilmesi daha uygundur. Bazı kesimlerin içerdiği glutenden ötürü tam ve rafine edilmiş ayrımı yapmadan buğdayı zararlı göstermeleri metodolojik eksikliklerden kaynaklanmakta olup, tüm tahıl tüketiminin kanser dahil olmak üzere bir dizi kronik hastalık riskinde azalma ile ilişkili olduğu $[109,110]$, rafine tahilları tüketenlerde ise kanser vakalarının daha fazla olduğu rapor edilmekle birlikte bu ilişkinin kesin olmadığı bildirilmektedir [111].

Tablo 2. Tam ve rafine buğdayın besin bileşimi ile rafinesyon sonucu oluşan kayıp [100, 112].

\begin{tabular}{|c|c|c|c|}
\hline Bileşenler & $\begin{array}{l}\text { Tam } \\
\text { buğday }\end{array}$ & $\begin{array}{l}\text { Rafine } \\
\text { buğday } \\
\text { unu }\end{array}$ & $\begin{array}{l}\text { Rafinesyon } \\
\text { ile kayıp } \\
\text { oranı (\%) }\end{array}$ \\
\hline Çözünmeyen diyetlifi $(\mathrm{g} / \mathrm{kg})$ & 115 & 19 & 83 \\
\hline Protein $(\mathrm{g} / \mathrm{kg}$ & 14 & 14 & 0 \\
\hline Yağ $(g / k g)$ & 27 & 14 & 48 \\
\hline Nişasta ve şeker ( $\mathrm{g} / \mathrm{kg})$ & 700 & 830 & -19 \\
\hline $\mathrm{Zn}(\mu \mathrm{g} / \mathrm{kg})$ & 29 & 8 & 72 \\
\hline $\mathrm{Fe}(\mu \mathrm{g} / \mathrm{g})$ & 35 & 13 & 63 \\
\hline $\mathrm{Se}(\mu \mathrm{g} / \mathrm{g})$ & 0.06 & 0.02 & 67 \\
\hline $\mathrm{Mg}(\mathrm{mg} / \mathrm{g})$ & 1.38 & 0.22 & 84 \\
\hline Vitamin $B^{6}(\mathrm{mg} / \mathrm{g})$ & 7.5 & 1.4 & 81 \\
\hline Folic acid (mg/g) & 0.57 & 0.11 & 81 \\
\hline Ferulic acid $(\mathrm{mg} / \mathrm{g})$ & 0.5 & 0.04 & 92 \\
\hline$\beta$ Tocotrienol $(\mu \mathrm{g} / \mathrm{g})$ & 32.8 & 5.7 & 83 \\
\hline
\end{tabular}

*: Verilen besin değerleri çeşitlere ve ülkelere göre değişebilir

Bilindiği üzere, hacimli ekmek elde etmeye esas rafine unda buğday danesinin kabuk ve ruşeyme kısımları atılmaktadır. Çünkü kepek ve diğer maddeler gluten ăg yapısına girerek hamurun reolojik özelliklerini, gaz tutma kapasitesini ve kabarmasını olumsuz yönde etkilemektedir [113]. Bu itibarla tam tane buğday ununun hammadde olarak kullanıldığı son ürünlerin üretiminde rafineri buğdaya göre karşılaşılan zorluklar nedeniyle buğday genotiplerini seçmede ve işleme teknolojilerini belirlemede daha dikkatli ve çok yönlü davranılması gerekmektedir. Fırıncılar pişirmede yaş gluten oranının yüksek olmasını arzu ederler. Daha büyük nişasta partikül boyutuna sahip TTBU numuneleri, rafine undan önemli ölçüde daha düşük gluten içeriklerine sahip olmaktadır. Tam buğday un haline getirilirken uygulanan öğütme teknolojisi, nişasta tanecik boyutundaki etkisi sebebiyle farklı hacimlerde ekmeklerin oluşmasına sebebiyet vermektedir. Bu sebeple tam buğday una işlenirken uygun partikül boyutunda olmalıdır [99]. Tam tanenin öğütme boyutunun küçültülmesi daha kaba hacimli bir ekmek elde edilmesini sağlamaktadır [114]. Bununla beraber, Noort ve ark. [115] tam buğday kabuğunun öğütme boyutunun küçültülmesinin pişme kalitesine olumsuz etki yaptığını bildirmişlerdir. Sert kabuğa sahip tam buğday unları genellikle daha yüksek su alım kapasitesi ve daha uzun hamur yoğurma süresine sahip iken, yumuşak kabuklu tam buğday unlarından daha küçük hacimli somun ekmek üretilmektedir [116]. Tam buğday tane rengi ile alakalı yapılan çalışmalarda, kırmızı çeşitlerle yapılan ekmeklerde bir miktar acılık hissedilirken, beyaz daneli buğdaylar ise daha tatlı bir his vermektedir [117-119]. Çeşitler arasındaki bu fark fenolik bileşik profillerindeki farklılıktan kaynaklanmaktadır [120]. 
Tam buğdayda rüşeymin oranı da ekmek hacminin belirlenmesinde esas alınmaktadır. Ruşeym oranı \%5'e düşürülen tam buğday unundan elde edilen mayalı hamurdan en yüksek ekmek hacmi elde edilmiştir [121]. Ancak bu konuda yeterli çalışma olduğu söylenemez. Bu sebeple tam buğday unundaki embriyo oranı ile embriyo içeriğini belirtmeye esas araştırmalara ihtiyaç vardır [116]. Nitekim buğday genotipleri arasında embriyo ebadı veya oranı bakımından farklılıklar olup aynı zamanda büyük embriyoya sahip genotipler daha uzun koleoptil oluşturmaktadır [122]. Islahçıların tam buğday esaslı seleksiyonlarında embriyo ebadı farkını gözetmelerinde fayda vardır. Ekmeklik buğday kalite araştırmaları çağunlukla endospermde bulunan depo proteinleri üzerinde odaklanmıştır. Protein oranı ile birlikte başta gluten olmak üzere alt unsurların ekmek kalitesine olan etkileri detayları ile açıklığa kavuşturulmaya çalışılmaktadır. Günümüzde protein oranı ve kalitesinin esas alındığı kalite çalışmalarında genetik ve çevrenin etkileşimleri sonucu birbirinden farklı özellikte çeşitler geliştirlimiştir. Bununla beraber söz konusu çeşitlilik embriyo ve kabuğun dahil edildiği tam buğday unlarınının içeriğini de etkilemiştir. Hocaoğlu ve ark. [123], 1967-2010 yılları arası Türkiye'de geliştirilen durum buğdaylarında $\mathrm{Ca}, \mathrm{Cu}$ ve $\mathrm{S}$ oranlar1 artarken, $\mathrm{Br}$ ve $\mathrm{Zn}$ mikro elementlerinde bir değişim olmadığını, $\mathrm{Na}$ oranında ise düşüş kaydedildiğini belirtmiş̧lerdir. Vignola ve ark. [124], genetik ve çevre şartlarının tanenin mineral içerik yanı sıra dış kabukta yer alan bir bileşik olan arabinoksilan içeriği ile tipi üzerinde de etkili olduğunu bildirmişlerdir. Yapılan çalışmalar $\mathrm{Fe}, \mathrm{Zn}, \mathrm{Cu}, \mathrm{Mn}$ ve $\mathrm{P}$ gibi mineral içerikleri bakımından buğday çeşitleri arasında büyük farklılıkların olduğunu göstermişir [124-126]. Tam buğday unları iyi bir mineral kaynağı olmasına rağmen, bu minerallerin nasıl absorbe edileceği ve dolayısıyla organizma tarafından nasıl kullanılacağı da dikkate alınmalıdır.

Öte yandan, genetik farklılığın diyet lifleri, B grubu vitaminler, bitkiye tat, renk ve lezzet sağlayan fenolik içeriği ve antioksidan kapasitesi ile diğer faydalı bileşiklerin oran ve içerikleri gibi özellikler üzerine etkileri de gözardı edilmemelidir. Nitekim Li [127] daha açık renkli genotiplerin polifenol ve flavonoid içeriğinin koyu olanlara göre daha düşük olduğunu bildirmişlerdir. $\mathrm{Bu}$ sebeple daha besleyici genotiplerin geliştirilmesinde genetik etki ihmal edilmememelidir [116].

Genetik farklılık tahılların diyet lif içeriği ve özellikleri üzerinde de büyük bir etkisi bulunmamaktadır [128]. Buğdayın ihtiva ettiği çok sayıda bileşenlerin oran ve bileşimlerindeki var olan kalıtsal varyasyonlar sebebiyle 1slahçı yüksek tane verimi ve agronomik özellikler ile birlikte insan sağlı̆̆ını eas alan kalite özelliklerini göz önünde bulundurarak çeşit geliştirmelidir [76]. Buğday kalite çalışmalarında tam buğday ununa olan talep artışları dikkate alındığında gelecek 10 yılda gerek uygun çeşitlerin tespiti ve gerekse işleme teknolojisinde açıklığa kavuşturulması gereken çok sayıda parametre olduğunu belirtmekte fayda vardır.

\section{SONUÇ ve ÖNERILER}

Tüm dünyada olduğu gibi ülkemizde de insanların beslenme rejiminin geçmişten günümüze oldukça fazla değiştiğini görmekteyiz. Özellikle batı tarzı beslenme biçiminin tüm dünyada yaygınlaştığını görmek mümkündür. Öyle ki günümüzde aşırı beslenmeden dolayı hastalanıp hayatını kaybedenlerin yetersiz beslenenlerin sayısından daha fazla olması dikkate değerdir [129]. Fiziki olarak daha çok çalışan eski toplumlar temel gıda bakımından tam tahıl ekmeği başta olmak üzere sınırlı sayıdaki gıda çeşitliliği ile ihtiyacı karşılarken, günümüzde değişen beslenme alışkanlıkları ile gıda sanayisinin gelişmesine bağlı artan besin çeşitliliğindeki arz, insanların gıda ihtiyaç listesini de uzatmıştır. İşlenmiş gıda üretiminde raf ömrünün uzatılmasına esas katkı maddelerinin kabul edilebilir sınırlar üzerinde ilave edilmesi insan sağlığını olumsuz bir şekilde etkileyebilmektedir. Günümüzde başta kanser olmak üzere birçok hastalık beslenme alışkanlığı ile ilişkilendirilmektedir. İnsanların temel gidası durumundaki ekmek, geçmişte tam tahıldan yapılmakta iken artan refah seviyesi, damak zevkine dayalı ürün çeşitliliği, muhafazasının kolaylığı ve bunu işleyen teknolojilerinin gelişmesi rafineri undan yapilan ürünlerin hâkimiyeti ile neticelenmiştir. Hastalıkların temelinde yatan unsurların başında rafineri unların geldiğini belirten raporlar ile şuurlu toplumların bunu fark ederek tam tahıl ürünlerine olan talepleri söz konusu ürünlere ait kalite özellikleri ile işleme teknolojilerinin belirlenmesini gündeme taşımıştır. Ülkemizde olduğu gibi [130] bazı devletlerin tam tahıllı ekmeklerinin firınlarda üretilmelerinin kanun ve yönetmeliklerle zorunlu hale getirmeleri işin ehemmiyetini göstermesi açısından kayda değerdir. Bilindiği üzere 1slahçıları üretici, sanayici ve tüketici isteklerini göz önünde bulundurarak 1slah amaçlarını belirlemektedirler. $\mathrm{Bu}$ sebeple rafineri unlarda ekmek kalitesini etkileyen endospermdeki depo proteinleri 1slahçı ve kalitecilerin temel araştırma konularını teşkil etmiştir. Beyaz ekmek kalite standartlarına uygun gerek ülkemizde ve gerekse dünyada yüzlerce çeşit buğday geliştirilmiştir. Beyaz ekmeğin pişme kalitesini belirleyen un randımanı, protein oranı ve unsurları (gluten vd) ile kül oranı ve diğer bileşenler üzerinde detaylı durulurken, tam buğday unlarda depo proteinleri ile birlikte gerek embriyo ve gerekse kabuk kısmında yer alan bileşenler üzerinde de durulmasını gerekli kılmaktadır. Son zamanlarda önemi anlaşılabilen tam buğday unları ile alakalı kaliteyi belirleme ve iyileştirmeye yönelik hızlı çalışmalar olmakla birlikte son ürün ekmek özelliklerini karşılayabilecek çeşit sayısı sınırlı olup kalite özelliklerinin sınırları da tam çizilebilmiş değildir. Bilindiği üzere tam buğday unlarının işlenmesi ve uzun süre depolanması rafineri unlara göre daha zordur. Ayrıca diğer bileşenlere göre tam buğday ununun önemli 
bir parçası olan embriyo ile alakalı çok sayıda çalışma olduğu da söylenemez. Tüm bunlarla beraber insan sağlığını esas alan tam buğday unu kalite çalışmaları ile alakalı öne çıkan hususlar aşağıda özetlenmeye çalışılmıştır;

a) Son yıllarda çölyak dışı buğday hassasiyetinin artan yaygınlığının sebebi tam bilinmemekle birlikte, muhtemel etmen olarak görülen hexaploid buğdaylar ile birlikte modern buğday işleme teknikleri ve paketlemede kullanılan katkı maddelerinin detayları araştırılmalıdır [24]. b) Çölyak dışı buğday hassasiyetindeki artışın yegâne etmeni olarak görülen rafineri buğday yerine tam buğday ürünlerinin tüketimi, başta diyabet olmak üzere birçok hastalıkların azaltılmasında önemli rol aldığı çok sayıda araştırmalarla teyit edilmektedir. c) Tam buğday kalite ıslahında; çölyak dışı buğday hassasiyeti olanlar için yeni, sentetik, lokal, siyez (einkorn) ve kavılca (emmer) buğday genotipleriyle detaylı ve mukayeseli çalışmaların yapılması ile daha az reaktif buğday genotiplerini belirlenmelidir. d) En az genotip kadar önemli kabul edilen ve glisemik indeksin düşürülmesine esas uygun işleme teknolojileri (ögütme ebadı, pişme süres vs) belirlenmelidir. e) Buğday gluteninin, dane bileşimindeki diğer unsurlar ile birlikte alınması, hassas olmayan insanlar için zararlı olmaktan öte tam buğday danesinde birbirleri ile dengeli halde bulunan gluten ve diğer bileşeneler (lif, vitamin vs) insan sağlığı açısından gereklidir. f) Hamur yoğurma özellikleri, ekmeğin hacmi, tat ve diğer özelliklerin belirlenmesinde depo proteinlerine ek olarak kabuk ve embriyo içerikleri de detaylı bir şekilde araştırılmalıdır. g) Faydalı olsa bile ihtiyacı aşan gıda tüketimlerinin zararlı duruma geçmesi ve hastalıklara sebebiyet vermesi kaçınılmaz olup sağlıklı toplumsal bir yapı için bilinçli tüketim teşvik edilmelidir. h) Buğday kalite 1slahçıları farklı kesimlere hitap edebilen ve pazar ihtiyaçlarını göz önünde bulundurarak fizyolojik, morfolojik ve adaptasyon bakımından geniş varyasyona sahip genotipler içinden uygun kalitede olanları seçip çeşit geliştirme imkânına sahiptirler. Dolayısıyla tam buğday kalite sslah amaçları belirlenirken, 1slahçı, üretici, değirmenci, fırıncı ve beslenme uzmanları birlikte karar vermeleri daha isabetli çeşitlerin geliştirilmesinde temel faktör olmalıdır. Bu çerçevede bölge şartlarına uygun çeşit seçimi ve yetiştirme teknikleri ile birlikte amaca uygun kalite ve tam buğday işleme teknolojilerinin geliştirilmesi ile insan sağlığına katkı sağlayan ürün piyasasındaki boşluk da doldurulmuş olacaktır.

\section{KAYNAKÇA}

[1] Braun H.J, Atlin G, Payne T. Multi-location testing as a tool to identify plant response to global climate change. In: Reynolds MP, editor. Climate change and crop production. Wallingford (UK): CABI Publishers, 2010.

[2] Tadesse W., Sanchez-Garcia M., Gizaw Assefa S., Amri A., Bishaw Z., Ogbonnaya FC., Baum M. Genetic Gains in Wheat Breeding and Its Role in Feeding the World. Crop Breed Genetics Genomics, 1 1-28, 2019.

[3] TMO. Toprak mahsulleri ofisi Genel müdürlüğü 2019 yılı hububat sektör raporu Ankara, http://www.tmo.gov.tr/Upload/Document/sektorraporlari/ hububat2019.pdf. (Erişim Tarihi:23.09.2020).

[4] Shahbandeh M., Per capita food use of wheat worldwide 2000-2019,

https://www.statista.com/statistics/237890/global-wheatper-capita-food-use-since-2000.

(Erişim Tarihi:23.09.2020).

[5] OECD-FAO 2018. Cereals. Agricultural Outlook 2018-2027, 2018. http://www.agrioutlook.org/commodities/Agricultural-Outlook-2018Cereals.pdf. (Erişim Tarihi: 23.09.2020).

[6] Delcour J.A., Joye I.J., Pareyt B., Wilderjans E., Brijs K., Lagrain B. Wheat gluten functionality as a quality determinant in cereal-based food products. Ann Rev Food Sci Technol, 3:1 469-492, 2012.

[7] Wrigley C.W. Wheat: a unique grain for the world. See Khan Shewry 2009, p. 1-17, 2009.

[8] Delcour J.A, Hoseney R.C. Principles of Cereal Science and Technology. St. Paul, MN: AACC Int. p. 270, 2010.

[9] Huebner F.R., Bietz J.A., Nelsen T., Bains G.S, Finney P.L. Soft wheat quality as related to protein composition.Cereal Chem, 76 650-555, 1999.

[10] Keçeli A. Turkish Journal of Agriculture-Food Science and Technology. Turkish Journal of Agriculture-Food Science and Technology, 7:12 2111-2120, 2019.

[11] Elgün, A., Ertugay, Z. Tahıl İşleme Teknolojisi, Atatürk Üniversitesi Ziraat Fakültesi Yayınları, Erzurum, No:718, s. 376, 1995.

[12] Anonim. Türkiye Beslenme ve Sağlık Araştırması 2010: Beslenme Durumu ve Alışkanlıklarının Değerlendirilmesi Sonuç Raporu. Sağlık Bakanlığı, https://hsgm.saglik.gov.tr/depo/birimler/sagliklibeslenme-hareketli-hayat-db/Yayinlar/kitaplar/digerkitaplar/TBSA-Beslenme-Yayini.pdf (Erişim tarihi: 27.11.2020).

[13] Kılıç H. Kur'an Işığında Tahıl Bitkileri. International Creation Congress on the light of sciences.30 November2 December 2017 Şanlıurfa Turkey .(Edit: Akan H., Erdoğan O., Küfrevioğlu İ.) International Creation Congress on The Light of Sciences Proceedings 30th November-2nd December 2107. Harran Üniv. Şanlıurfa 2018.

[14] Kılıç H. Tahılların Başağında Saklanması. II. Uluslararası Bilimler Işı̆̆ında Yaratılış Kongresi (8-9 Kasım 2018 Atatürk Üniversitesi Erzurum) s. 383-392, 2018.

[15] Koning F. Adverse Effects of Wheat Gluten. Ann Nutr Metab, 67:2 7-14, 2015.

[16] Davis W.R. Wheat Belly: Lose the Wheat, Lose the Weight, and Find Your Path Back to Health. https://www.amazon.com/Wheat-Belly-Lose-WeightHealth-ebook/dp/B00571F26Y, (Erişim Tarihi 14.02.2021). 
[17] You W., Henneberg M. Cereal Crops Are not Created Equal: Wheat Consumption Associated with Obesity Prevalence Globally and Regionally AIMS Public Health, 3:2 313-328, 2016.

[18] Abadie V., Sollid L.M., Barreiro L.B., Jabri B. Integration of genetic and immunological insights into a model of celiac disease pathogenesis. Ann. Rev. Immunol. 29, 493-525, 2011.

[19] Karell K., Louka A.S., Moodien S.J., Ascher H., Clot F., Greco L., Ciclitira P.J., Sollid L.M. an Partanen J. HLA types in celiac disease patients not carrying the DQA1*05-DQB1*02 (DQ2) heterodimer: results from the European Genetics Cluster on celiac disease. Hum. Immunol., 64 469-477, 2003.

[20] Volta U, Caio G, Tovoli F, De Giorgio R. Non-celiac gluten sensitivity: questions still to be answered despite increasing awareness. Cell Mol Immunol., 10 383-92, 2013.

[21] Venter C., Maslin K., Arshad S.H., Patil V., Grundy, J., Glasbey G., Twiselton R., Dean T. Very low prevalence of IgE mediated wheat allergy and high levels of crosssensitisation between grass and wheat in a UK birth cohort. Clin Transl Allergy, 6:1 1-7, 2016.

[22] Brouns F.J., van Buul V.J., Shewry P.R. Does wheat make us fat and sick? Journal of Cereal Science, 58:2 209-215, 2013.

[23] Hauner H., Bechthold A., Boeing H., Brönstrup A., Buyken A., Leschik-Bonnet E. Evidence-Based Guideline of the German Nutrition Society: Carbohydrate Intake and Prevention of Nutrition-Related Diseases. Deutsche medizinische Wochenschrift (1946), 137:8 389393, 2012.

[24] Kucek L.K., Veenstra L.D., Amnuaycheewa P., Sorrells M.A. Grounded Guide to Gluten: How Modern Genotypes and Processing Impact Wheat Sensitivity. Comprehensive Reviews in Food Science and Food Safety, 14 285-302, 2015.

[25] Kim H.S., Patel K.G., Orosz E., Kothari N.F., Demyen M., Pyrsopoulos N.K., Ahlawat S. Time trends in the prevalence of celiac disease and gluten-free diet in the us population: results from the National Health and Nutrition Examination Surveys 2009-2014. JAMA Intern Med, 176 1716-1717, 2016.

[26] Reilly N.R. The gluten-free diet: recognizing fact, fiction and fad. J Pediatr., 175 206-210, 2016.

[27] Biesiekierski J.R., Peters S.L., Newnham E.D., Rosella O., Muir J.G., Gibson P.R. No effects of gluten in patients with self-reported non-celiac gluten sensitivity after dietary reduction of fermentable, poorly absorbed, short-chain carbohydrates. Gastroenterology, 145 320328, 2013.

[28] Niland B., Brooks D.C., Health Benefits and Adverse Effects of a Gluten-Free Diet in Non-Celiac Disease Patients Gastroenterol Hepatol., 14:2 82-91, 2018.
[29] Wünsche J., Lambert C., Gola U., Biesalski H.K. Consumption of gluten free products increases heavy metal intake. NFS Journal, 12 11-15, 2018.

[30] Zong G., Lebwohl B., Hu F.B., Sampson L., Dougherty L.V., Willett W.C., Chan A.T., Sun Q.I. Gluten intake and risk of type 2 diabetes in three large prospective cohort studies of US men and women. Diabetologia, 61 2164-2173, 2018.

[31] Liu S., Stampfer M.J., Hu F.B., Giovannucci E., Rimm E., Manson J.E., Hennekens C.H., Willett W.C. Wholegrain consumption and risk of coronary heart disease: results from the Nurses' Health Study. Am J Clin Nutr., 70 412-419, 1999.

[32] Johnsen, N.F., Frederiksen K., Christensen J. Wholegrain products and whole-grain types are associated with lower all-cause and cause-specific mortality in the Scandinavian HELGA cohort. British Journal of Nutrition, 114:4 608-623, 2015.

[33] Slavin J.L., Martini M.C., Jacobs D.R., Marquart L. Plausible mechanisms for the protectiveness of whole grains. The American Journal of Clinical Nutrition, 70:3 459-463, 1999.

[34] McRae M.P. Health Benefits of Dietary Whole Grains: An Umbrella Review of Meta-analyses J Chiropr Med., 16:1 0-18, 2017.

[35] Dubois B., Bertin P., Mingeot D. Molecular diversity of alpha-gliadin expressed genes in genetically contrasted spelt (Triticum aestivum ssp. spelta) accessions and comparison with bread wheat ( $\mathrm{T}$. Aestivum ssp. aestivum) and related diploid Triticum and Aegilops species. Molecular Breeding, 36:11 1-15, 2016.

[36] Dubois B., Bertin P., Hautier L., Muhovski Y., Escarnot E., Mingeot D. Genetic and environmental factors a_ecting the expression of alpha-gliadin canonical epitopes involved in celiac disease in a wide collection of spelt (Triticum aestivum ssp. spelta) cultivars and landraces. BMC Plant Biol. 18, 262, 2018.

[37] Escarnot E., Goot S., Sinnaeve G., Dubois B., Bertin P., Mingeot D. Reactivity of gluten proteins from spelt and bread wheat accessions towards A1 and G12 antibodies in the framework of celiac disease. Food Chem. 268 522532, 2018.

[38] Malalgoda M., Ohm J.B., Simsek Ş. Celiac antigenicity of ancient wheat species. Foods, 8:12 675, 2019.

[39] Rajaram S., Borlaug N.E., Van Ginkel M. CIMMYT international wheat breeding. In: Curtis BC, Rajaram S, Gomez Macpherson H, editors. Bread Wheat Improvement and Production. FAO, Rome, p. 103-117, 2002.

[40] Shaw L.M., Turner A.S., Laurie D.A. Impact of photoperiod insensitive Ppd-1a mutations on the photoperiod pathway across the three genomes of hexaploid wheat (Triticum aestivum). The Plant Journal, 71:1 71-84, 2012.

[41] Ausemus E.R., Reitz L.P. Hard red spring and durum wheats: culture and varieties. USDA Agric Info 249 US 
Government Printing Office, Washington, D.C, 1962.

[42] Liu D., Zhang L., Hao M., Ning S., Yuan Z., Dai S. Wheat breeding in the hometown of Chinese Spring. The crop Journal, 6 82-90, 2018.

[43] Borlaug, N.E. Wheat breeding and its impact on world food supply. In K.W. Finlay K.W. Shephard, eds. Proceedings of the 3rd International Wheat Genetics Symposium, p. 1-36. Canberra, Australia, Australian Academy of Sciences, 1968.

[44] Hoogendoorn, J., Pfeiffer, W.H., Rajaram, S., Gale, M.D. Adaptive aspects of dwarfing genes in CIMMYT germplasm. In T.E. Miller R.M.D Koebner, eds. Proceedings of the 7th International Wheat Genetics Symposium, p. 1093-1100. Cambridge, UK, 1988.

[45] Li A., Liu D., Yang W., Kishii M., Mao L. Synthetic Hexaploid Wheat: Yesterday, Today, and Tomorrow. Engineering, 4 552-558, 2018.

[46] CIMMYT. Extensive use of wild grass-derived "synthetic hexaploid wheat" adds diversity and resilience to modern bread wheat, 2019. https://www.cimmyt.org/news/extensive-use-of-wildgrass-derived-synthetic-hexaploid-wheat-adds-diversityand-resilience-to-modern-bread-wheat (Erişim Tarihi:02.12.2020).

[47] Aktaş H., Karaman M., Erdemci İ., Kendal E., Tekdal S., Kılıç K., Oral E. Sentetik ve Modern Ekmeklik Buğday Genotiplerinin (Triticum aestivum L.) Verim ve Kalite Özelliklerinin Karşılaştııılması. Uluslararası Tarım ve Yaban Hayatı Bilimleri Dergisi, 3:1 25-32, 2017.

[48] Calderini D.F., Ortiz-Monasterio I. Grain position affects grain macronutrient and micronutrient concentrations in wheat. Crop Sci., 43:1 141-51, 2003.

[49] Kempe K., Rubtsova M., Gils M. Split-gene system for hybrid wheat seed production. Proc Natl Acad Sci., 111 9097-9102, 2014.

[50] Gowda M., Longin C.F.H., Lein V., Reif J.C. Relevance of specific versus general combining ability in winter wheat. Crop Sci., 52 2494-2500, 2012.

[51] Longin C.F.H., Gowda M., Mühleisen J., Ebmeyer E., Kazman E., Schachschneider R., Schacht J., Kirchhoff M., Zhao Y., Reif J.C. Hybrid wheat: quantitative genetic parameters and consequences for the design of breeding programs. Theor Appl Genet., 126 2791-2801, 2013.

[52] Tian B., Talukder S.K., Fu J., Fritz AK. Trick H.N. Expression of a rice soluble starch synthase gene in transgenic wheat improves the grain yield under heat stress conditions. In Vitro Cellular Developmental Biology-Plant, 54:3 216-227, 2018.

[53] Weichert N., Saalbach I., Weichert H., Kohl S., Erban A., Kopka J., Hause B., Varshney A., Sreenivasulu N., Strickert M., Kumlehn J., Weschke W., Weber H. Increasing sucrose uptake capacity of wheat grains stimulates storage protein synthesis, Plant Physiology, 152:2 698-710, 2010.

[54] Li S., Wang N., Wang Y., Fang J., He G. Inheritance and expression of copies of transgenes $1 \mathrm{Dx} 5$ and $1 \mathrm{Ax} 1$ in elite wheat (Triticum aestivum L.) varieties transferredfrom transgenic wheat through conventional crossing, Acta Biochimica et Biophysica Sinica, 39:5 377-383, 2007

[55] Mao M., Li Y., Zhao S., Zhang J., Lei Q., Meng D., Ma F., Hu W., Chen M., Chang J., Wang Y., Yang G. He G. The interactive efects of transgenically overexpressed 1Ax1 with various HMW-GS combinations on dough quality by introgression of exogenous subunits into an elite Chinese wheat variety, PLoS One, 8:10 e78451, 2013.

[56] Morgounov A.I., Belan I., Zelenskiy Y., Roseeva L., Tomoskozi S., Bekes F., Abugalieva A., Cakmak İ., Vargas M. Crossa J. Historical changes in grain yield and quality of spring wheat varieties cultivated in Siberia from 1900 to 2010, Can. J. Plant Sci., 93:3 425-433, 2013.

[57] Bornhofen E., Benin G., Storck L., Marchioro V.S., Meneguzzi C., Milioli A.S., Trevizan D.M. Environmental effect on genetic gains and its impact on bread-making quality traits in Brazilian Spring Wheat Chilean Journal of Agricultural Research, 77:1 27-34, 2017.

[58] Nehe A., Akin B., Sanal T., Evlice A., Ünsal R., Demir L., Geren H., Sevim İ., Orhan Ş., Yaktubay S., Ezici A., Guzman C., Morgounov A. Genotype x environment interaction and genetic gain for grain yield and grain quality traits in Turkish spring wheat released between 1964 and 2010. Plos One, 14:7 e0219432, 2019.

[59] Karagöz A., Wheat landraces of Turkey. Emir. J. Food Agric.. 26 149-156, 2014.

[60] Davis K.R., Cain R.F., Peters L.J., Le Tourneau D., McGinnis J. Evaluation of the nutrient composition of wheat. II. proximate analysis, thiamin, riboflavin, niacin, and pyridoxine. Cereal Chem., 58 116-20, 1981.

[61] Wadhawan C.K, Bushuk W. Studies on vitality of commercial gluten. II. Solubility fractionation, electrophoresis, and flourescence results. Cereal Chem., 66 461-466, 1989.

[62] Wieser H., Seilmeier W. The influence of nitrogen fertilisation on quantities and proportions of different protein types in wheat flour. J Sci Food Agric., 76 49-55, 1998.

[63] Posner E.S. Wheat. In: Kulp K, Ponte JG, editors. Handbook of cereal science and technology. $2^{\text {nd }} \mathrm{ed}$. New York, NY: Marcel Dekker, Inc. p. 1-29, 2000.

[64] Gafurova D.A., Tursunkhodzhaev P.M., Kasymova T.D., Yuldashev P.K. Factional and amino-acid composition of wheat grain cultivated in Uzbekistan. Chem Nat Compd., 38 377-379, 2002.

[65] Huynhand B.L., Palmer L., Mather D.E., Wallwork H., Graham R.D., Welch R.M., Stangoulis J.C.R. Genotypic variation in wheat grain fructan contentrevealed by a simplified HPLC method. J Cereal Sci., 48 369-378, 2008. 
[66] Özdemir S. Glutenin Fraksiyonunun Elektroforetik Özellikleri Üzerine Un Randımanı ve Yoğurma Sicaklığının Etkisi. Yüksek Lisans Tezi, Uludağ Üniversitesi Fen Bilimleri Enstitüsü, Gıda Mühendisliği Anabilim Dalı, s. 55, 2007.

[67] Dizlek H. Buğdaydaki Gluten Proteinleri: Gliadin. Akademik Gıda, 10:2 109-114, 2012.

[68] Žilić S. Wheat Gluten: Composition And Health Effects In: Gluten. Edit: Dane B. Walter. Chapter IV. Nova Science Publishers, Inc. 2013.

[69] Payne P.I., Holt L.M., Jackson E.A., Law C.N. Wheat storage proteins: Their genetics and their potential for manipulation by plant breeding. Philosophical Transactions Biological Sciences, 304:1120 359-371, 1984.

[70] Kaya Y., Akçura M. Effects of genotype and environment on grain yield and quality traits in bread wheat (T. aestivum L.) Food Sci. Technol. Campinas, 34:2 386-393, 2014.

[71] Kılıç H., Sanal T., Erdemci İ. Karaca K. Screening Bread Wheat Genotypes for High Molecular Weight Glutenin Subunits and Some Quality Parameters. Journal Agriculture Science Techonologies, 19 1393-1404, 2017.

[72] Aktaş H., Şener O. Effect of hmw and lmw glutenin alleles on quality traits of bread wheat Genetika, 52:1 257-271, 2020.

[73] Molberg Q., Uhlen A.K., Jensen T., Flæte N.S., Fleckenstein B., Arentz-Hansen H., Raki M., Lundin K.E., Sollid L.M. Mapping of gluten T-cell epitopes in the bread wheat ancestors: implications for celiac disease. Gastroenterology, 128 393-401, 2005.

[74] Spaenij-Dekking L., Kooy-Winkelaar Y., van Veelen P., Drijfhout J.W., Jonker H., van Soest L., Smulders M.J.M., Bosch D., Gilissen L.J.W.J., Koning F. Natural variation in toxicity of wheat: potential for selection of nontoxic varieties for celiac disease patients. Gastroenterology, 129 797-806, 2005.

[75] Van Herpen T.W.J.M., Goryunova S.V., Van der Schoot J., Mitreva M., Salentijn E., Vorst O., Schenk M.F., van Veelen P.A., Koning F., van Soest L.J.M. Alpha-gliadin genes from the $\mathrm{A}, \mathrm{B}$, and $\mathrm{D}$ genomes of wheat contain different sets of celiac disease epitopes. BMC Genomics, 7:1 1-13, 2006.

[76] Pizzuti D., Buda A., D’Odorico A., D’Inca R., Chiarelli S., Curioni A., Martines D. Lack of intestinal mucosal toxicity of Triticum monococcum in celiac disease patients. Scand. J. Gastroenterol, 41 1305-1311, 2006.

[77] Shewry P.R., Hey S.J. The contribution of wheat to human diet and health Food and Energy Security, 4:3 178-202, 2015.

[78] Shewry P.R., Hey S. Do "ancient" wheat species differ from modern bread wheat in their contents of bioactive components Journal of Cereal Science, 65 236-243, 2015.

[79] Zanini B., Villanacci V., De Leo L., Lanzini A. Triticum monococcum in patients with celiac disease: A phase II open study on safety of prolonged daily administration. Eur. J. Nutr., 54 1027-1029, 2015.

[80] Fasano A. Zonulin and Its Regulation of Intestinal Barrier Function: The Biological Door to Inflammation, Autoimmunity, and Cancer Physiol Rev., 91 151-175, 2011.

[81] Fasano A. Zonulin, regulation of tight junctions, and autoimmune diseases Ann N Y Acad Sci., 1258:1 25-33, 2012.

[82] Drago S., El Asmar R., Di Pierro M., Clemente M.G., Tripathi A., Sapone A., Thakar M., Iacono G., Carroccio A., D'Agate C., Not T., Zampini L., Catassi C., Fasano A. Gliadin, zonulin and gut permeability: Effects on celiac and non-celiac intestinal mucosa and intestinal cell lines Gastroenterol, 41:4 408-19, 2006.

[83] Lammers K.M., Lu R., Brownley J., Lu B., Gerard C., Thomas K., Rallabhandi P., Shea-Donohue T., Tamiz A., Alkan Ş., Netzel-Arnett S., Antalis T., Vogel S.N., Fasano A. Gliadin induces an increase in intestinal permeability and zonulin release by binding to the chemokine receptor CXCR3. Gastroenterology, 135:1 194-204, 2008

[84] Hollon J., Puppa E.L., Greenwald B., Goldberg E., Guerrerio A., Fasano A. Effect of gliadin on permeability of intestinal biopsy explants from celiac disease patients and patients with non-celiac gluten sensitivity Controlled Clinical Trial Nutrients, 7:3 1565-1576, 2015.

[85] Sander G.Y., Cummins A.G., Henshall T., Powell B.C. Rapid disruption of intestinal barrier function by gliadin involves altered expression of apical junctional proteins chemokine receptor CXCR3. Gastroenterology, 135:1 194-204, 2008.

[86] Biesiekierski J.R., Newnham E.D., Irving P.M., Barrett J.S., Haines M., Doecke J.D., Shepherd S.J., Muir J.G., Gibson P.R. Gluten causes gastrointestinal symptoms in subjects without celiac disease: a double-blind randomized placebo-controlled trial. Am J Gastroenterol, 106:3 508-514, 2011.

[87] Hajifaraji M., Rezvani V., Yaghoobi A.S., Morteza H., Madda M. Glycemic indices of three commonly consumed foods: a clinicaltrial in Iranian healthy adults Mediterr J Nutr Metab., 1:1 3-7, 2008.

[88] Ridner E., Di Sibio A. Glycemic index of two varieties of pasta and two varieties of rice Arch Latinoam Nutr Archivos Latinoamericanos de Nutrición, 65:2 79-85, 2015.

[89] Modu S., Laila A., Zainab A.M., Bintu B.P. Studies on the glycemic response of wheat at various level of processing fed to normal healthy rats, Biochemistry, 23:2 63-71, 2011.

[90] Ergün R. Türkiye’ye özgü bazı ekmek türlerinin glisemik indeks değerlerinin saptanmas1. Hacettepe Üniversitesi Sağlık Bilimleri Enstitüsü Beslenme Bilimleri Progra mı Yüksek Lisans Tezi, Ankara, 2014

[91] Joubert S. Glycemic index and glycemic load for 100+ foods August 22, 2017 By Your Side Ltd 
https://byyoursidehomecare.co.uk/glycemic-indexglycemic-load-100-foods/ (Erişim Tarihi:17.02.2021).

[92] Nylund L., Kaukinen K., Lindfors K. The microbiota as a component of the celiac disease and non-celiac gluten sensitivity. Clinical Nutrition Experimental, 6 17-24, 2016.

[93] Bektaş A., ÖzeL M. Gluten: Dost mu, Düşman mı? Güncel Gastroenteroloji, 22:2 127-134, 2018.

[94] Muir J. Is a carbohydrate called fructan giving gluten a bad rap? Monash Univ.2019 https://lens.monash.edu/@health-sciences/2019/ 08/01/1375992/gut-feeling-is-a-carbohydratecalled-fructan-giving-gluten-a-bad-rap-1, (Erişim Tarihi 17.02.2021).

[95] Payne P.I. Genetics of wheat storage proteins and the effect of allelic variation on bread-making quality. Annu Rev Plant Physiol., 38:1 141-53, 1987.

[96] Metakovsky E.V., Knezevic D., Javornik B. Gliadin allele composition of Yugoslav winter wheat cultivars. Euphytica, 54:3 285-295, 1991.

[97] Salentijn E.M., Esselink D.G., Goryunova S.V., van der Meer I.M., Gilissen L.J.W.J., Smulders M.J.M. Quantitative and qualitative differences in celiac disease epitopes among durum wheat varieties identified through deep RNA-amplicon sequencing. BMC Genomics, 14:1 1-16, 2013.

[98] Nakamura A., Tanabe S., Watanabe J., Makino T., Station A.E., April R. Primary screening of relatively less allergenic wheat carieties. J Nutr Sci Vitaminol, 51 204216, 2005.

[99] Bressiani J., Oro T., Santetti G.S., Almeida J.L., Bertolin T.E., Gomez M., Gutkosk L.C. Properties of whole grain wheatflour and performance in bakeryproducts as a function of particle size Journal of Cereal Science, 75 269-277, 2017.

[100] Thompson L.U. Potential health benefits of whole grains and their components. Contemporary Nutrition, 17 1-2, 1992.

[101] Liu R.H. Whole grain phytochemicals and health Journal of Cereal Science, 46:3 207-219, 2007.

[102] Lafiandra D., Riccardi G., Shewryc P.R. Improving cereal grain carbohydrates for diet and health. J Cereal Sci., 59 312-26, 2014.

[103] Zong G., Gao A., Hu F.B., Sun Q. Whole grain intake and mortality from all causes, cardiovascular disease,and cancer: A meta-analysis of prospective cohort studies. Circulation, 133, 2370-2380, 2016.

[104] Benisi-Kohansal, S., Saneei P., Salehi-Marzijarani M., Larijani B., Esmaillzadeh A. Whole-grain intakeand mortality from all causes, cardiovascular disease, and cancer: A systematic review and dose-responsemetaanalysis of prospective cohort studies. Adv. Nutr., 16:7 1052-1065, 2016.

[105] Kaur K.D., Jha A., Sabikhi L., Singh A.K. Significance of coarse cereals in health and nutrition: a review. J Food Sci Technol., 51 1429-41, 2014
[106] Slavin J. Whole grains and human health Nutrition Research Reviews, 17:1 99-110, 2004.

[107] Hadjivassiliou M., Grunewald R.A., Sharrack B., Sanders D., Lobo A., Williamson C., Woodroofe N., Wood N., Davies-Jones A. Gluten ataxia in perspective: epidemiology, genetic susceptibility and clinical characteristics, Brain, 126 685-69, 2013.

[108] Mizrak G. Glisemik indeks, glisemik yük, sağl1kl beslenme ve spor. Ziraat mühendisliği. Aralık, 363, 2016.

[109] Kyro C., Tjonneland A. Whole grains and public health. BMJ., 353 i3046, 2016.

[110] U.S. Department of Health and Human Services, 2015. U.S. Department of Agriculture. 2015-2020 Dietary Guidelines for Americans 8th Edition, 2016, http://health.gov/dietaryguidelines/2015/guidelines/ (Erişim Tarihi: 17 Ocak 20201).

[111] Gaesser G.A. Whole Grains, Refined Grains, and Cancer Risk: A Systematic Review of Meta-Analyses of Observational Studies Nutrients, 12:12 3756, 2020.

[112] Murtaugh M.A., Jacobs D.R., Jacob B., Steffen L.M., and Marquart L. Epidemiological support for the protection of whole grains against diabetes Proceedings of the Nutrition Society, 62 143-149, 2003.

[113] Taşçı R., Karabak S., Bolat M., Pehlivan A., Şanal T., Acar O., Külen S., Güneş E., Albayrak M. Ankara İlinde Ekmek Fırınlarının Üretim Yapısı ve Ekmek İsrafı TEAD, 3:1 1-16, 2017.

[114] Lai C.S., Hoseney R.C., Davis A.B. Effects of wheat bran in breadmaking. Cereal Chem., 66:3 217-219, 1989.

[115] Noort M.W.J., Haaster D., Hemery Y., Schols H.A., Hamer R.J. The effect of particle size of wheat bran fractions on bread quality: Evidence for fibre-protein interactions. J. Cereal Sci., 52 59-64, 2010.

[116] Gomez M., Gutkoski L.C., Núñe A.B. Understanding whole-wheat flour and its effect in breads: review Compr Rev Food Sci Food Saf., 19 3241-3265, 2020.

[117] McGuire C.F., O'Palka J. Sensory evaluation of a hard white compared to a hard red winter wheat. Journal of the Science of Food and Agriculture, 67:1 129-133, 1995

[118] Talbert L.E., Hofer P., Nash D., Martin J.M., Lanning S.P., Sherman J.D., Giroux M.J. Hard white versus hard red wheats: Taste tests and milling and baking properties. Cereal Chemistry, 90:9 249-255, 2013.

[119] Benisi-Kohansal, S., Saneei P., Salehi-Marzijarani M., Larijani B., Esmaillzadeh A. Whole-grain intakeand mortality from all causes, cardiovascular disease, and cancer: A systematic review and dose-responsemetaanalysis of prospective cohort studies. Adv. Nutr., 16:7 1052-1065, 2016.

[120] Watts B., Ryland D., Malcolmson L.J., Ambalamaatil S., Adams K.M., Lukow O.M. Flavor properties of pan and pita breads made from red and white hard spring wheats. Journal of Food Quality, 35:1 60-68, 2012.

[121] Gomez M., González J., Oliete B. Effect of extruded wheat germ on dough rheology and bread quality. Food and Biopro-cess Technology, 5:6 2409-2418, 2012. 
[122] Nik M.M., Babaeian M., Tavassoli A. Effect of seed and embryo size on early growth of wheat genotypes African Journal of Microbiology Research, 5:27 4859-4865, 2011.

[123] Hocaoğlu O., Akçura M., Kaplan M. Changes in the Grain Element Contents of Durum Wheat Varieties of Turkey Registered between 1967-2010. Journal Communications in Soil Science and Plant Analysis, 51:4 431-439, 2020.

[124] Vignola M.B., Moiraghi M., Salvucci E., Baroni V., Pérez G.T. Whole meal and white flour from Argentine wheat genotypes: Mineral and arabinoxylan differences.Journal of Cereal Science, 71 217-223, 2016.

[125] Monasterio I., Graham R.D. Breeding for trace minerals in wheat. Food and Nutrition Bulletin, 21:4 392-396, 2000.

[126] Akçura M., Hocaoğlu O., Kılıç H., Kökten K. Karadeniz Bölgesine Ait Yerel Ekmeklik Buğday Hatlarının Tanedeki Besin Elementleri İçerikleri Yönünden Tescilli Ekmeklik Buğday Çeşitleri İle Karşılaştırılması. Türkiye X. Tarla Bitkileri Kongresi, 2013.

[127] Li Y., Ma D., Sun D., Wang C., Zhang J., Xie Y., Guo T. Total phenolic, flavonoid content, and antioxidantactivity of flour, noodles, and steamed bread made fromdifferent colored wheat grains by three milling methods The Crop Journal, 3 328-334, 2015.

[128] Mulero M.C., Barros L., Fernandes A., Ferreira I., Callejo J., González M., Ruiz V.F., Morales P., Carrillo J.M. Potential Health Claims of Durum and Bread Wheat Flours as Functional Ingredients Nutrients, 12:2 504, 2020.

[129] Selimoğlu E., Bektaş Y., Özkocak V., Gültekin T. Beslenme Şeklinin Zaman İçindeki Tarihsel Yolculuğu. SETSCI Conference Indexing System, 3 390-398, 2018.

[130] TGK. Türk Gıda Kodeksi Ekmek ve Ekmek Çeşitleri Tebliği Resmi Gazete: 04.01.2012 tarih ve 28163 sayılı Tebliğ No: 2012/2, 2012. 